JOURNAL OF THE SOUTH AFRICAN INSTITUTION OF CIVIL ENGINEERING ISSN 1021-2019

Vol 63 № 3, September 2021, Pages 62-70, Paper 1060

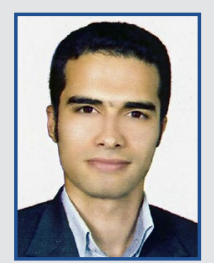

EHSAN SANADGOL is a PhD student in Water Engineering and Hydraulic Structures at the Estahban Branch of the Islamic Azad University in Iran. He also serves on the staff of Iran's Ministry of Roads and Urban Development

Contact details:

Department of Civil Engineering

Estahban Branch

Islamic Azad University

Estabahn

Iran

T: +989112801066

E: ehsansanadgol@yahoo.com

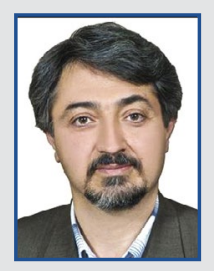

PROF MANOUCHEHR HEIDARPOUR is a Ful Professor of Hydraulic Engineering at the Isfahan University of Technology, Iran. His research focuses mainly on hydraulic structures, sediment transport hydraulics, local scouring, and hydraulic jump. He received his PhD in Hydraulic Engineering from the University of Ottawa, Canada

(1997), an MSc in Water Engineering from Shiraz University, Iran (1990), and a BSc in Water Engineering (1986) from the Isfahan University of Technology (1986). After he had obtained his PhD in 1997, he joined the staff at the Isfahan University of Technology where he was promoted to Associate Professor in 2005, and to Full Professor in 2010.

Contact details:

Department of Water Engineering

College of Agriculture

Isfahan University of Technology

Isfahan

Iran

T: +989133109744

E: heidar@iut.ac.ir

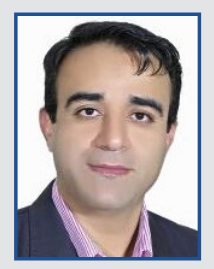

DR REZA MOHAMMADPOUR is Assistant Professor in the Department of Civil Engineering at the Islamic Azad University, Estahban Branch, Iran. He received his PhD from the Department of River Engineering and Urban Drainage (REDAC) at the USM University in Malaysia where he also did his post-doctoral research. He is still a member of USM's academic staff in the Faculty of Engineering. His main research areas are environmental hazards, water quality, local scour, sediment transport, water pollution and climate change. He has published and presented numerous papers in/at various journals and conferences.

\section{Contact details:}

Assistant Professor

Department of Civil Engineering

Estahban Branch

Islamic Azad University

Estabahn

Iran

T: +989173134112

E: reza564@gmail.com

\title{
scouring at round-nosed rectangular piers using a downstream bed sill
}

\author{
E Sanadgol, M Heidarpour, R Mohammadpour
}

This study investigated the effectiveness of bed sills in reducing the scour depth with time at rectangular piers in a laboratory. Experiments were conducted just below the threshold of sediment motion $(U / U c=0.95)$ for round-nosed piers with the length-to-width ratios of $L / b=1$, 2, 3 and 4. Accordingly, a $1 \mathrm{~cm}$ thick PVC section as wide as the channel was used as the bed sill, which was flush with the bed and located at various distances, $D$, in the downstream of the piers, i.e. $D / b=0,1,2$ and 3 . It was found that the efficiency of the bed sill for a rectangular pier was significantly less than that for the circular one; there was a decrease in efficiency and scour depth with an increase of the pier length. The maximum efficiency obtained for the round-nosed piers with $L / b=1,2,3$ and 4 was $32.5 \%, 21.3 \%, 14.4 \%$ and $5.7 \%$, respectively. The application of a bed sill to reduce the local scour in round-nosed rectangular piers, when the length-to-width ratio exceeds 2 , is therefore not recommended. Furthermore, the efficiency of the bed sill is the best when it is attached to the downstream end of the pier; its efficiency is decreased when increasing its distance from the pier.

\section{INTRODUCTION}

The occurrence of local scouring is one of the main reasons for the instability and failure of bridges. Lefter (1993), and Lagasse and Richardson (2001) postulated that the main cause of the failure of bridges in the United States of America was a local scouring phenomenon. Chiew and Lim (2003), and Chiew (2004) reported several breakdowns of bridges in the south of Taiwan. Dey and Barbhuiya (2004) also observed the failure of bridges in New Zealand due to a local scouring phenomenon. In this regard Ghorbani and Kells (2008) stated that the lack of pier protection measures against local scouring would disrupt the transportation system, in addition to the failure of bridges, and financial and human costs.

Different countermeasures have been proposed and tested in the literature to reduce the local scour hole dimensions at bridge piers. These can generally be categorised into three distinct groups, namely armouring, flow altering and structural countermeasures. The first method is to increase the resistance of the bed to the shear stress. This is done by replacing the materials around the pier with a protective layer of materials such as riprap, gabion, blocked cables or prefabricated concrete moulds. The objective of the second method is to reduce the power of the eroding causes, i.e. the downflow and the horseshoe vortex, which are mainly responsible for producing scouring around the pier. The flow-altering countermeasures involve one of the following three methods: (1) connecting some form of assemblies in the upstream of the pier (e.g. sacrificial piles), (2) altering the shape of the pier, and (3) providing the scour reduction devices on the pier (e.g. collars, plates or slots). The third method involves the modification of the bridge structure (foundation). Typically, the substructure is modified to increase the bridge stability after scour has occurred or when there is a scour-critical bridge. These modifications are generally classified as either foundation strengthening or pier geometry modifications (Lagasse et al 2009).

Bed sills are usually employed for river training purposes, e.g. in high-gradient streams, to prevent excessive bed degradation. They can also be arranged in sequence, producing a stair-like configuration of artificial steps, to reduce the velocity and erosive capacity of the watercourse (Gaudio et al 2000; Lenzi et al 2003;

Martín-Vide \& Andreatta 2009). Bed sills could affect the general channel morphology; however, they have also been shown to be able to act as countermeasures against 
bridge pier scour (Chiew \& Lim 2003; Gaudio et al 2012; Grimaldi et al 2009a \& 2009b; Pagliara et al 2010; Razi et al 2011; Tafarojnoruz et al 2012a \& 2012b).

Grimaldi et al (2009a) showed that the scour depth reduction could reach to approximately $26 \%$ in the best tested configuration (bed sill adjacent to the pier). Grimaldi et al (2009b) also proposed a combined countermeasure consisting of a slot and a bed sill placed downstream of the pier and adjacent to it. In the best configuration, the scour reduction in the upstream front of the pier was approximately $45 \%$, on average (with approximately $80 \%$ and $90 \%$ for the scour area and volume, respectively). Further, Pagliara et al (2010) analysed the efficiency of sills and gabions as countermeasures against local scour in the presence of a simplified debris geometry. They found that, although a delay occurred in the scour development, the countermeasure efficiency was insufficient for the large scour development in the presence of large debris accumulation, while gabions were able to further delay the scour process, mainly due to the larger surface roughness, as compared with the smooth sills. Tafarojnoruz et al (2012a) also showed that a single bed sill downstream of a pier had the maximum efficiency, which was less than $20 \%$, with $D / b=0$ ( $D$ was the distance between the downstream end of the pier and bed sill, and $b$ was the diameter or the width of the pier, as shown in Figure 2). Tafarojnoruz et al (2012b) used a combination of the bed sill and collar for a circular pier under steady flow conditions, as well as for a rectangular pier with a round nose and tail, two circular in-line piers and two rectangular in-line piers. The results showed that the combined countermeasure had the efficiency of almost $63 \%$ for a single circular pier; however, higher efficiency (approximately 75\%) was obtained in applications related to the rectangular pier and two in-line circular or rectangular piers. Further, Gaudio et al (2012) studied the combined flow-altering countermeasures against the bridge pier scour: (1) submerged vanes and a bed sill, and (2) a bed sill and a collar. The results showed that combination (1) did not reduce the scour depth significantly, with respect to the single countermeasure and combination; for combination (2), in the best configuration, the scour depth was significantly reduced around the collar with respect to the maximum scour depth of the unprotected pier, as well as prevented the scour hole from reaching the pier body.
Bridge piers are mainly circles, squares, rectangles, rectangular corners and roundnosed rectangular shapes. Investigations on the effect of the bed sill on the reduction of local scouring indicate that the research has mainly been carried out on circular piers. However, round-nosed rectangular piers are widely used in bridges, and the performance of the bed sills on roundnosed rectangular piers is of great interest. There is limited information regarding the application of bed sills for rectangular piers. The objective of this work was, therefore, to study the effectiveness of the bed sill downstream of a round-nosed rectangular pier when the distance between the bed sill and pier and the length-to-width ratio of the pier were changed.

\section{MATERIALS AND METHODS}

\section{Dimensional analysis}

The relation between the depth of the local scour at a round-nosed rectangular bridge pier, $d_{s}$, and a bed sill located at a distance, $D$, in the downstream (Figure 2), and its dependent parameters can be written as follows:

$$
\begin{aligned}
d_{s e}= & f\left(g, \rho, v, U, y, B, d_{50}, \sigma_{g}, U_{c}, \rho_{s}^{\prime},\right. \\
& L, b, S h, A I, D, t)
\end{aligned}
$$

Where: $d_{s e}$ is the equilibrium scour depth in the upstream front of the pier, $g$ is the acceleration of gravity, $\rho$ is water density, $v$ is kinematic viscosity, $U$ is the mean approach flow velocity, $y$ is the mean approach flow depth, $B$ is the width of the flume cross section, $d_{50}$ is the median diameter size of the sediment, $\sigma_{g}$ is the geometric standard deviation of the sediment particle, $U_{c}$ is the mean approach flow velocity at the threshold condition for the sediment movement, $\rho_{s}^{\prime}$ is the submerged sediment density, $L$ is the rectangular pier length, $b$ is the rectangular pier width, $S h$ is the parameter describing the shape, $A l$ is the parameter describing the alignment of the pier, $D$ is the distance between the pier and bed sill, and $t$ is the time.

The Buckingham theorem, applied to Equation 1 , by choosing $\rho, U$ and $b$ as the basic variables, leads to:

$$
\begin{aligned}
\frac{d_{s}}{b}= & f_{1}\left(\frac{U}{U_{c}}, \frac{U}{\sqrt{g b}}, \frac{U b}{v}, \frac{y}{b}, \frac{B}{b}, \frac{\rho_{s}^{\prime}}{\rho}, \sigma_{g}, \frac{b}{d_{50}},\right. \\
& \left.\frac{D}{b}, \frac{U t}{b}, \frac{L}{b}, S h, A I\right)
\end{aligned}
$$

Where: $U / U_{c}$ is termed the flow intensity, $U / \sqrt{g b}$ and $U b / v$ are known as "pier Froude number" $\left(F_{p}\right)$ and "pier Reynolds number" $\left(R_{p}\right)$, respectively, $y / b$ is the flow shallowness, $\rho_{s}^{\prime} / \rho$ is the submerged sediment specific gravity, $\sigma_{g}$ is the sediment nonuniformity, $b / d_{50}$ is the sediment coarseness, $U_{\mathrm{t}} / b$ is a time scale for the development of scour, and $L / b$ is the aspect ratio for a rectangular pier.

A lot of research has been done to determine the effect of the dimensionless groups in Equation 2 on the local scour depth. According to Franzetti et al (1994), if the pier Reynolds number is greater than 7000 , the effect of viscosity on the local scouring process can be ignored. If $y / b \geq 2$, the flow shallowness effect does not occur and the depth does not influence scouring (Laursen \& Toch 1956; Breusers et al 1977; Melville \& Sutherland 1988; Franzetti et al 1994). Laursen and Toch (1956), and Hager and Oliveto (2002) reported that if $B / b \geq 10$, the channel side wall effects on the local scour could be eliminated and the contracted scour would not happen. Laboratory data also showed that the local scour depth was independent of the sediment size when $b / d_{50} \geq 20-25$ (Ettema 1980; Chiew 1984; Breusers \& Raudkivi 1991; Melville \& Coleman 2000). For sand and gravel, $\rho_{s}^{\prime} / \rho$ is almost constant and can be eliminated from Equation 2. When a rectangular pier is aligned with the flow direction (the flow angle of attack is zero), the pier alignment effects are assumed to be absent. For $\sigma_{g}<1.3$, the sediment can be considered uniform. It is assumed that their influence in Equation 2 is the same, even in the presence of a bed sill. The maximum scour depth is achieved under a condition close to the motion initiation, i.e. $U / U_{c} \approx 1$.

Given the above conditions, for the present study, the dimensionless scour depth can be simplified as follows:

$\frac{d_{s}}{b}=f_{2}\left(\frac{D}{b}, \frac{U t}{b}, \frac{L}{b}\right)$

At equilibrium, i.e. when the dimensions of the scour hole stop increasing and remain constant, Equation 3 becomes:

$\frac{d_{s}}{b}=f_{3}\left(\frac{D}{b}, \frac{L}{b}\right)$

$U / U_{c}$ represents the stage of the sediment transport on the approach flow bed, termed the flow intensity. In the present study, all experiments were conducted 


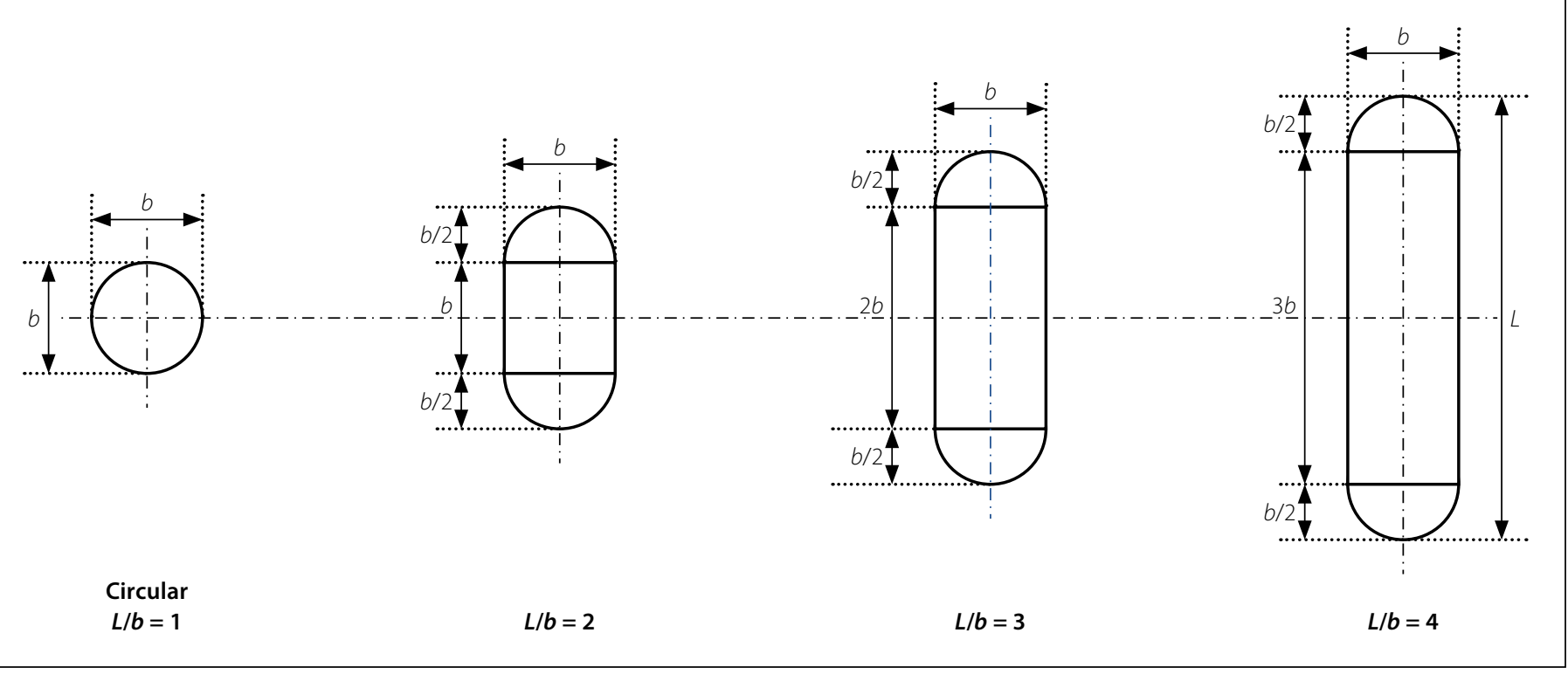

Figure 1 Pier models used in the experiments

under weak transport conditions, so a small number of the smallest particles were in motion at the isolated zones, according to the definition given by (Kramer 1935), i.e. $U / U_{c}=0.95$. In the following sections, the influence of these parameters on the local scour depth is discussed.

\section{Experimental set-up and procedure}

The experiments were conducted in an $11 \mathrm{~m}$ long, $0.42 \mathrm{~m}$ wide and $0.6 \mathrm{~m}$ deep plexiglasssided tilting recirculating experimental flume. At the inlet, a honeycomb box was placed to straighten the flow streamlines and minimise the turbulent velocity fluctuations. The test section, in which piers and the bed sill were located, was $2 \mathrm{~m}$ long with a recess on the bed $0.2 \mathrm{~m}$ deep; it was situated $6 \mathrm{~m}$ downstream from the entrance of the flume to guarantee a fully developed flow. To determine a fully developed region, velocity profiles were measured along the flow from the flume inlet in case no bed was installed in the channel, and a fully developed flow was observed downstream far from the flow inlet, where there was no detectable change of velocity profiles in the flow direction. The recess was filled in with a nearly uniform coarse sand (median diameter: $d_{50}=0.72 \mathrm{~mm}$; geometric standard deviation: $\left.\sigma_{g}=\left(d_{84} / d_{16}\right)^{0.5}=1.2\right)\left(d_{16}=\right.$ grain size for which $16 \%$ by weight of the sediment was finer, and $d_{84}=$ grain size for which $84 \%$ by weight of the sediment was finer). A gravel ramp was placed downstream of the honeycomb, creating a progressive increase in elevation to obtain a gradual change in the test section. The slope of the gravel ramp was equal to $1 \mathrm{~V}: 6 \mathrm{H}$ and its length was $1.2 \mathrm{~m}$. Discharge was measured with an

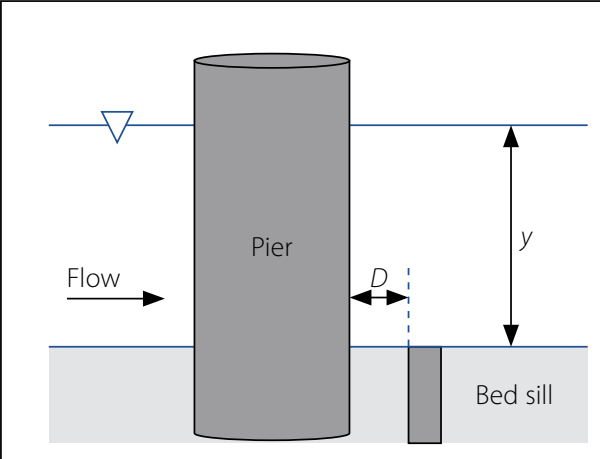

(a)

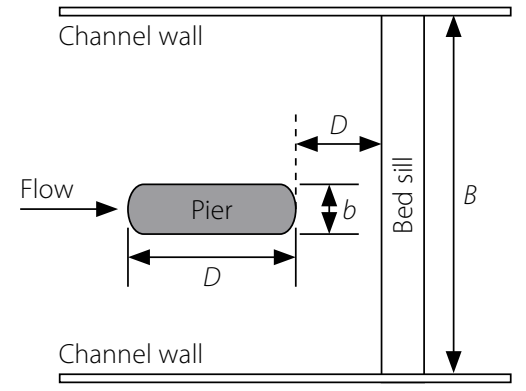

(b)
Figure 2 Illustration of a bed sill installed downstream of a rectangular pier: (a) side view and (b) plan view electromagnetic flowmeter located on the supply pipes with the accuracy of $0.1 \mathrm{l} / \mathrm{s}$, and the flow depths and bed level were in front of each pier with a point gauge having the accuracy of $0.1 \mathrm{~mm}$. At the end of the flume, a sluice gate was used to adjust the water surface level. The bed topography was manually measured on a grid size of $3 \mathrm{~cm} \times 3 \mathrm{~cm}$ (sometimes $1 \mathrm{~cm} \times 1 \mathrm{~cm}$, depending on the bed topography) over the pier. The grid pattern was dense to obtain the accurate bed topography at the end of each experiment.

One circular and three round-nosed rectangular piers were tested. The circular pier had a diameter of $30 \mathrm{~mm}$, and three round-nosed piers with a width of $30 \mathrm{~mm}$ and a length of 60,90 and $120 \mathrm{~mm}$ were applied, i.e. $L / b=2,3$ and 4 . The piers were positioned at the centreline of the middle cross-section of the mobile bed. The round-nosed rectangular piers were aligned with the flow direction (the flow angle of attack was zero), so that the pier alignment effects could be assumed to be zero. Figure 1 shows the pier models used in the experiments. A $1 \mathrm{~cm}$ thick PVC section as wide as the channel, flush with the bed and extended to the bottom of the channel, was used as the bed sill, at different distances, $D$. Figure 2 represents a sketch of the bed sill installed downstream of the rectangular pier. Table 1 shows the flow conditions in the experimental tests.

Twenty tests were performed. Tests were designed according to the values
Table 1 Flow conditions in the experimental tests

\begin{tabular}{|c|c|c|c|c|c|c|c|c|}
\hline $\begin{array}{c}\boldsymbol{d}_{\mathbf{5 0}} \\
(\mathbf{m m})\end{array}$ & $\begin{array}{c}\mathbf{Q} \\
\left(\mathbf{m}^{\mathbf{3} / \mathbf{s})}\right.\end{array}$ & $\begin{array}{c}\boldsymbol{U} \\
(\mathbf{m} / \mathbf{s})\end{array}$ & $\begin{array}{c}\boldsymbol{y} \\
(\mathbf{m})\end{array}$ & $\begin{array}{c}\boldsymbol{U}_{*_{\boldsymbol{c}}} \\
(\mathbf{m} / \mathbf{s})\end{array}$ & $\begin{array}{c}\boldsymbol{U}_{\boldsymbol{c}} \\
(\mathbf{m} / \mathbf{s})\end{array}$ & $\mathbf{U}_{*} / \mathbf{U}_{*_{\mathbf{c}}}$ & $\mathbf{F r}$ & $\mathbf{R e}$ \\
\hline 0.72 & 0.0213 & 0.327 & 0.155 & 0.02 & 0.344 & 0.95 & 0.265 & 50685 \\
\hline
\end{tabular}


reported in Table 2. The first column shows the name of the test. The first letter shows the shape of the pier, i.e. C stands for the circular pier and $\mathrm{R}$ represents the round-nosed rectangular pier. The first number in the circular and rectangular piers shows the aspect ratio, i.e. the length-to-width ratio, $L / b$. The second number represents the relative distance between the pier and bed sill, $D / b$. Tests C1, R2, R3 and R4 were carried out without countermeasures and were used as the reference to evaluate the effectiveness of the countermeasure. In Table 2 , the term \%RDP or percentage reduction of the pier scour depth at equilibrium is defined as $\left(d_{s e 0}=\right.$ equilibrium scour depth in front of the pier without countermeasure):

$\% \mathrm{RDP}=\frac{d_{s e 0}-d_{s e}}{d_{s e 0}} \times 100 \%$

All experiments were continued until reaching the equilibrium state. Several criteria have been suggested in literature to recognise the equilibrium condition. Cardoso and Bettess (1999) considered that equilibrium could be reached if, by plotting $d_{s}$ versus $\log \mathrm{t}$, the variation of the slope is recognised in the plot; $d_{s}$ follows a nearly horizontal trend. Franzetti et al (1994) suggested that equilibrium could be achieved if $U_{\mathrm{t}} / b>2 \times 10^{6}$. Kumar et al (1999) assumed that the time of equilibrium was achieved when the variation in the scour depth was less than $1 \mathrm{~mm}$ in a three-hour period. Vittal et al (1994) also defined the equilibrium time as the one when the local scour depth variations in a six-hour period was less than $1 \mathrm{~mm}$. Melville and Chiew (1999) considered that the equilibrium condition was reached when the variation of the local scour depth $\left(d_{s}\right)$ in a one-hour period was less than $5 \%$ of the pier diameter (for circular piers) or width (for rectangular). In this research, all tests were continued until the criteria proposed by Vittal et al (1994) were satisfied. It was found that the value of the scour depth in the final six hours was less than $1 \mathrm{~mm} 14$ hours after starting the experiments. Therefore, all experiments were continued for a period of 15 hours.

The $U_{c}$ value was measured in preliminary tests when the pier was not installed. These tests showed that, with $0.155 \mathrm{~m}$ flow depth and $0.02 \mathrm{~m}^{3} / \mathrm{s}$ discharge, the bed material would be at the incipient motion. The ratio of shear velocity in these experiments, calculated from flow depth and energy slope, to the critical shear velocity,

Table 2 Geometric parameters of the piers and bed sill, and the maximum scour depth at equilibrium and efficiency

\begin{tabular}{|c|c|c|c|c|c|c|c|}
\hline Test & $\underset{(\mathrm{mm})}{L}$ & $\begin{array}{c}b \\
(\mathrm{~mm})\end{array}$ & $L / b$ & $\begin{array}{c}D \\
(\mathrm{~mm})\end{array}$ & $D / b$ & $\begin{array}{c}d s \\
(\mathrm{~cm})\end{array}$ & $\begin{array}{c}\text { RDP } \\
\%\end{array}$ \\
\hline $\mathrm{C} 1$ & 30 & 30 & 1 (circular) & - & - & 6.15 & - \\
\hline $\mathrm{C} 1-0$ & 30 & 30 & 1 (circular) & 0 & 0 & 4.15 & 32.5 \\
\hline C1-1 & 30 & 30 & 1 (circular) & 30 & 1 & 4.57 & 25.7 \\
\hline C $1-2$ & 30 & 30 & 1 (circular) & 60 & 2 & 4.75 & 22.8 \\
\hline C1-3 & 30 & 30 & 1 (circular) & 90 & 3 & 4.95 & 19.5 \\
\hline R2 & 60 & 30 & 2 & - & - & 5.85 & - \\
\hline R2-0 & 60 & 30 & 2 & 0 & 0 & 4.60 & 21.3 \\
\hline R2-1 & 60 & 30 & 2 & 30 & 1 & 4.80 & 17.9 \\
\hline R2-2 & 60 & 30 & 2 & 60 & 2 & 4.95 & 15.4 \\
\hline$R 2-3$ & 60 & 30 & 2 & 90 & 3 & 5.01 & 14.3 \\
\hline R3 & 90 & 30 & 3 & - & - & 5.55 & - \\
\hline R3-0 & 90 & 30 & 3 & 0 & 0 & 4.75 & 14.4 \\
\hline R3-1 & 90 & 30 & 3 & 30 & 1 & 4.90 & 11.7 \\
\hline R3-2 & 90 & 30 & 3 & 60 & 2 & 5.00 & 9.9 \\
\hline R3-3 & 90 & 30 & 3 & 90 & 3 & 5.05 & 9.0 \\
\hline R4 & 120 & 30 & 4 & - & - & 5.25 & - \\
\hline R4-0 & 120 & 30 & 4 & 0 & 0 & 4.95 & 5.7 \\
\hline R4-1 & 120 & 30 & 4 & 30 & 1 & 5.01 & 4.6 \\
\hline R4-2 & 120 & 30 & 4 & 60 & 2 & 5.06 & 3.6 \\
\hline R4-3 & 120 & 30 & 4 & 90 & 3 & 5.10 & 2.9 \\
\hline
\end{tabular}

as calculated from the Shields diagram, was approximately 0.95 . The results were compatible with the equations proposed by Laursen (1963), Goncharov (1964), Neill (1967) and Garde (1970).

\section{RESULTS AND DISCUSSION}

\section{Experimental observations}

During the first few minutes of the experiments, the bed sill was flush with the surface of the sediment recess and did not interfere with the horseshoe and wake vortices. During this time, the scour was initiated at the side of the pier, where the high shear stress occurred from the separated flow before it was propagated to the front face of the pier where the horseshoe vortex was located. As time passed and the scour hole grew around the pier, the scour around the bed sill occurred and the bed sill emerged. As the bed sill emerged, its impact on the flow field started and the scour rate was decreased; the greater the distance between the bed sill and the pier, the later the emergence of the bed sill. By reducing the distance between the bed sill and the pier, it had a greater impact on the wake vortices; so, when the bed sill was attached to the pier, it destroyed the wake, as well as affected the horseshoe vortices. With the increase of the bed sill distance from the pier, the impact of it on the horseshoe vortices was reduced, only affecting the lower part of the wake vortices. In the downstream of the bed sill, the local scour was observed. The maximum local scour downstream of the bed sill occurred at a distance approximately $35 \%$ of the scour hole length. The same observation was reported by Gaudio et al (2000), Gaudio and Marion (2003), Tregnaghi et al (2007) and Grimaldi et al (2009a). The width of the scour region downstream of the pier with bed sill was almost twice that for a pier without bed sill. It suggested that the lower part of the wake vortices interacted with the bed sill and deviated laterally. As a result, the lateral movement of the wake vortices caused the scour hole to become wider. The lateral deviation of the wake vortices also created two symmetrical holes downstream of the bed sill. All eroded sediments around the pier and bed sill were deposited in the form of a downstream hill. Figure 3 shows 

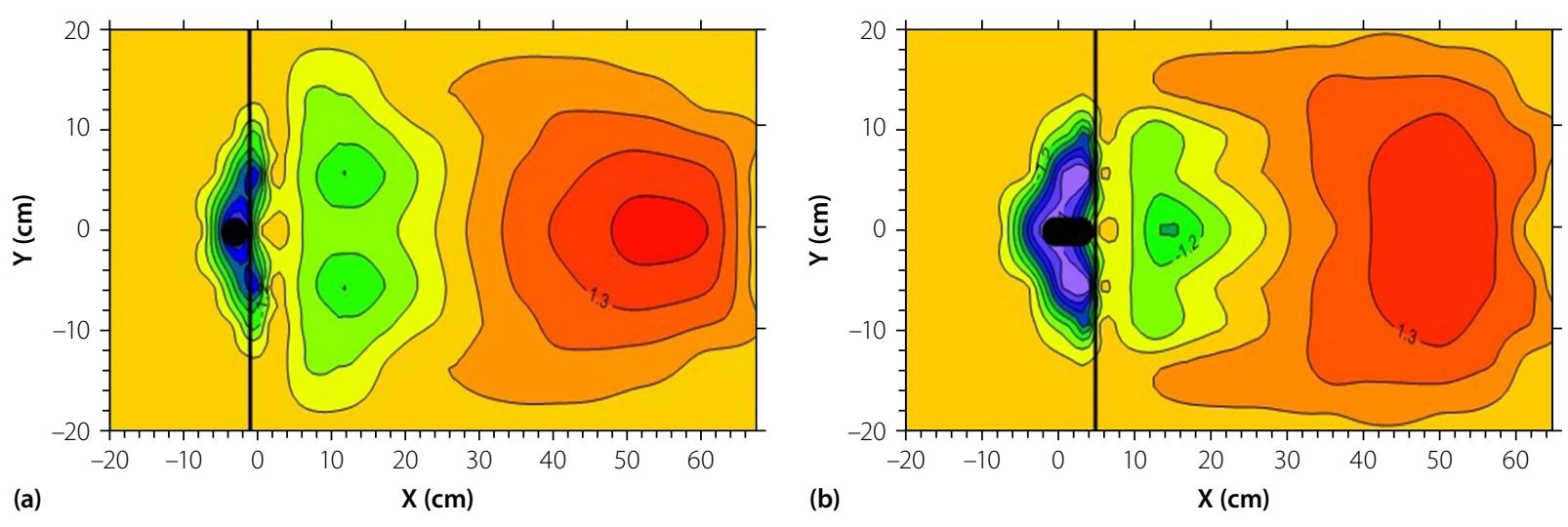

Z (cm)

(b)
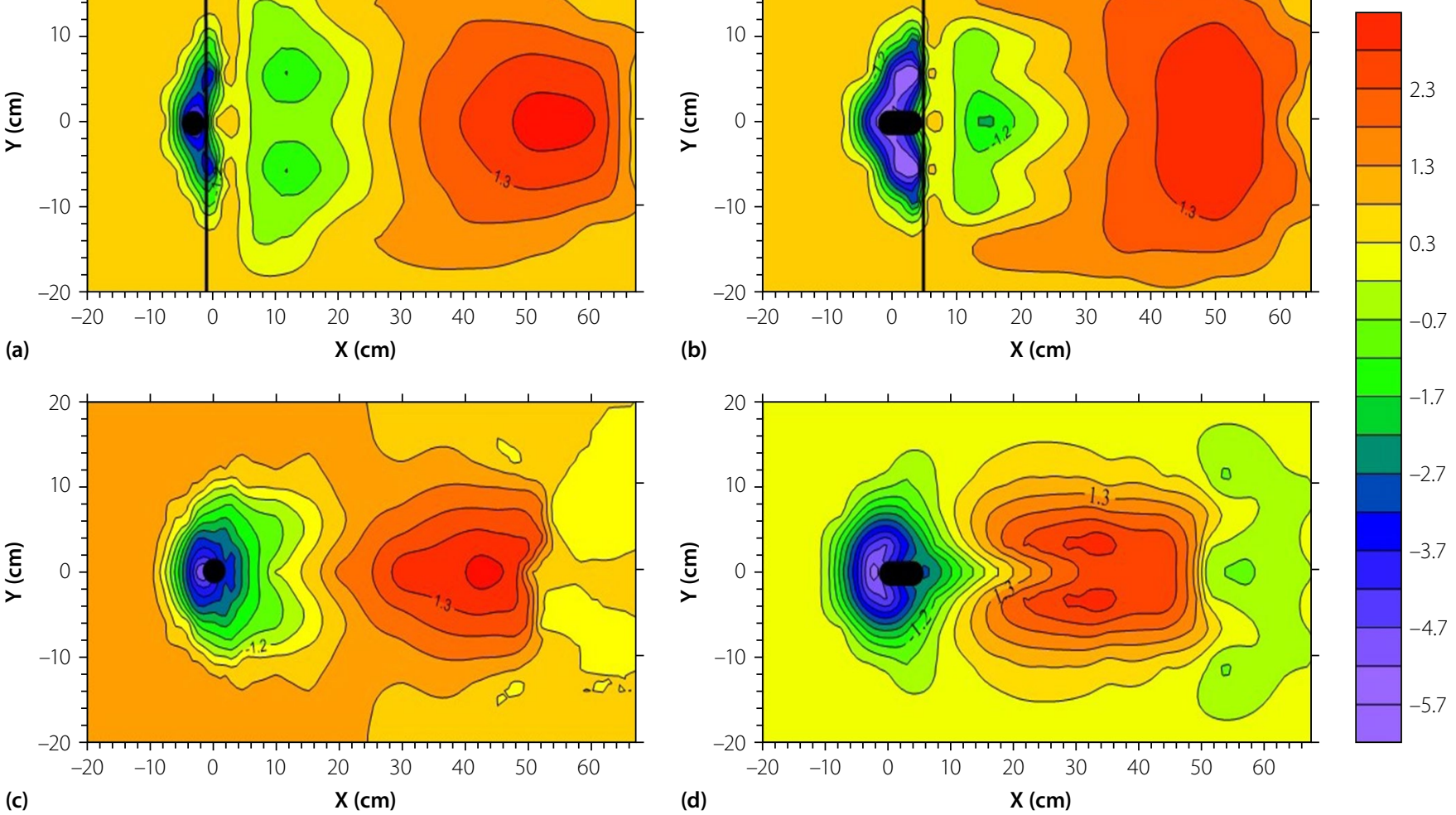

Figure 3 Contour lines of the equilibrium scour hole around the pier with and without the bed sill for tests (a) C1-0, (b) R2-0, (c) C1 and (d) R2

the contour lines of the equilibrium scour hole around the pier with and without the bed sill for tests C1-0, R2-0, C1 and R2. The images of the scour hole at the bed sill in the laboratory for tests C1-0 and R2-0 are also shown in Figure 4.

\section{Temporal development of the local scour around the circular pier}

Figure 5 shows the temporal development of the local scour around the circular pier without countermeasure (Test C1). It can be seen from Figure 5 that approximately $95 \%$ of the local scour depth occurred in the first six hours. Local scour depth was increased progressively with time, reaching equilibrium. Three segments could be recognised as the initial, principal and equilibrium segments. Three quantitative references of the time evolution of the scour depth around circular piers have been added for comparison purposes, i.e. Melville and Chiew (1999), Barkdoll et al (2000) and Guo (2014). The results of the current study were more consistent with those of Melville and Chiew (1999). Although there was a weak agreement between the studies presented in Figure 5 at the initial and principal stages, the results were close at the final equilibrium stage. The difference between the results could be attributed to different experimental conditions, e.g. different flow intensity, $U / U_{c}$. The maximum scour depth, using the equation developed by Lee and Strum (2009), was $7.75 \mathrm{~cm}$, indicating a good agreement with the results of the present study.

\section{Temporal development of} the local scour depth in the piers without bed sill

Figure 6 presents the temporal variations of the scour depth for circular and round-nosed rectangular piers without bed sill. As can be clearly seen at all phases of temporal development, the scour depth at the round-nosed rectangular piers was lower than that of the circular pier. In addition, the scour depth difference for the round-nosed rectangular piers with different lengths in the initial times of temporal development was low; however, over time, this difference increased. The results, as shown in Figure 6, indicated that in the round-nosed rectangular piers,

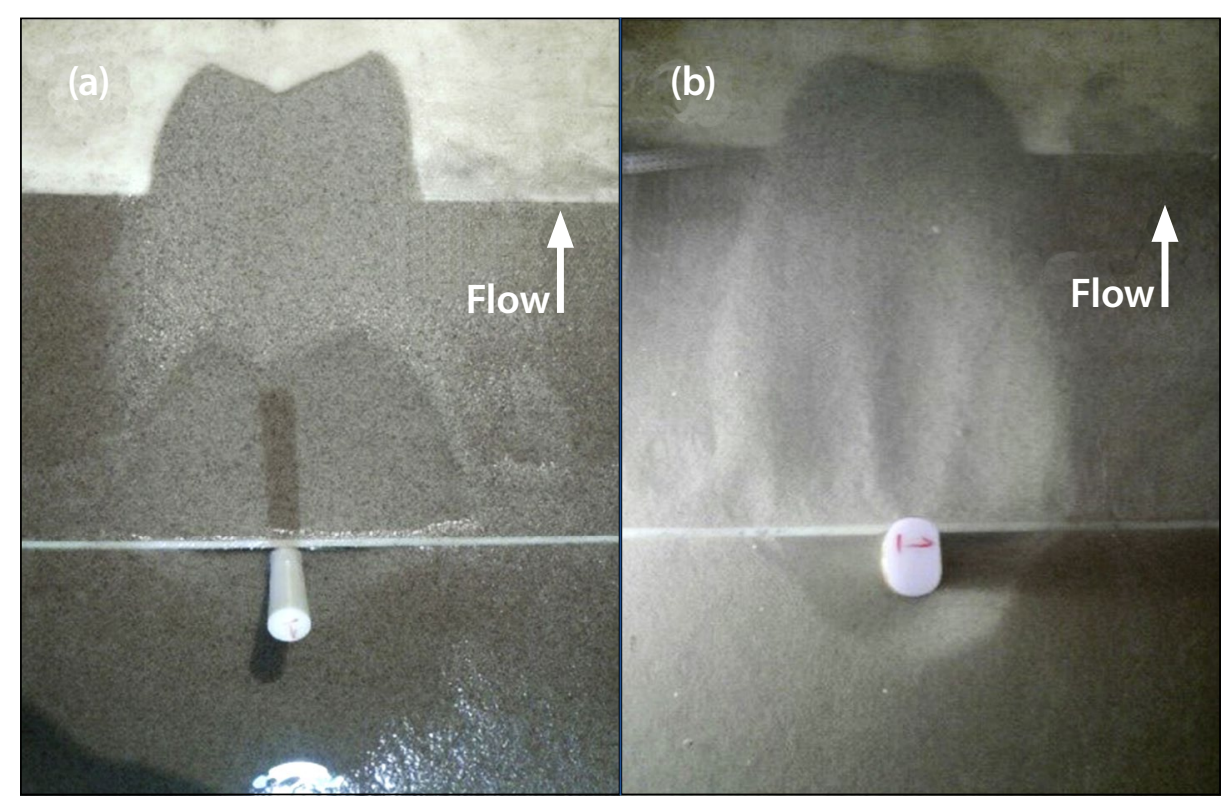

Figure 4 Images of the scour hole at the bed sill in the laboratory for tests (a) C1-0 and (b) R2-0 


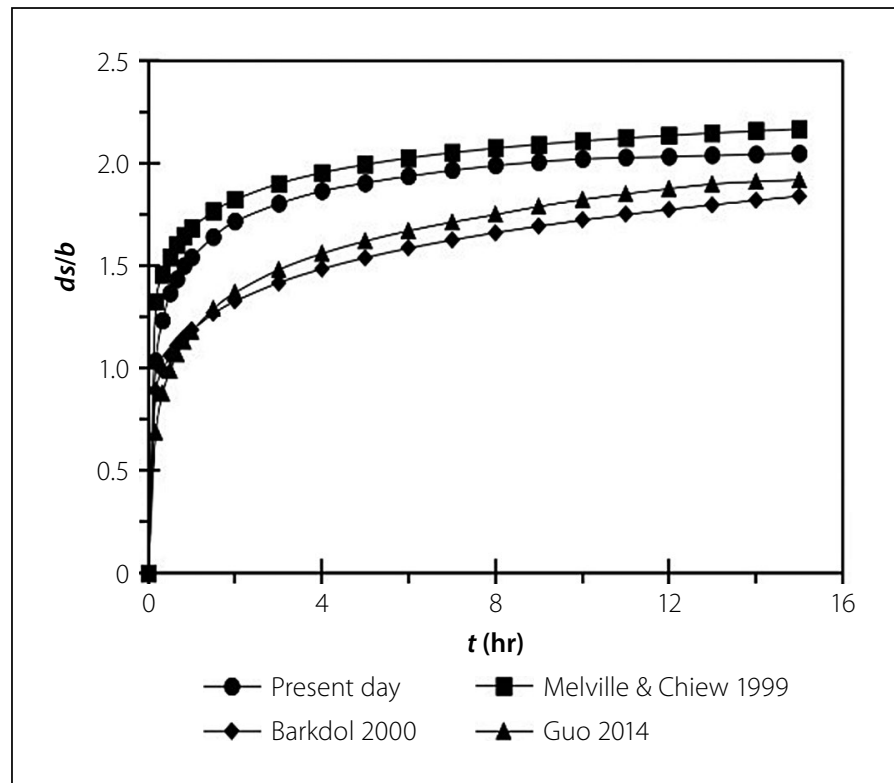

Figure 5 Temporal development of the local scour around the circular pier without countermeasure (Test C1) and comparison with other studies

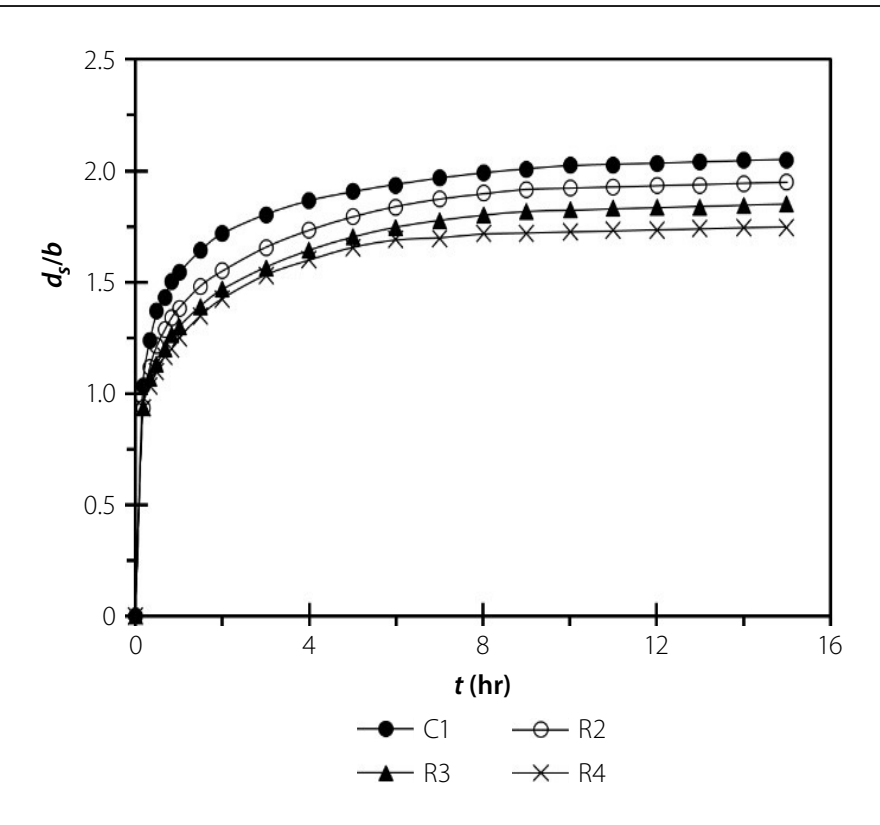

Figure 6 Temporal variations of the scour depth in the piers without bed sill the pier with the shorter length $(L=60$ $\mathrm{mm}$ ) had more scour depth, whereas the lower scour depth occurred at the pier with the larger length $(L=120 \mathrm{~mm})$. This is due to the horseshoe vortex, after forming in front of the pier, moving along the pier to its downstream end; so, the longer the pier, the weaker the horseshoe vortex. A reduction of the strength of the wake vortices resulted in less sediment being transported from the back of the pier. This could have an impact on the transportation of sediment from the front to the back of the pier.
Temporal development of the local scour depth in the piers with bed sill

The effect of increase $(L / b)$ on the local scour depth

Temporal scour depth variations in the circular and round-nosed rectangular

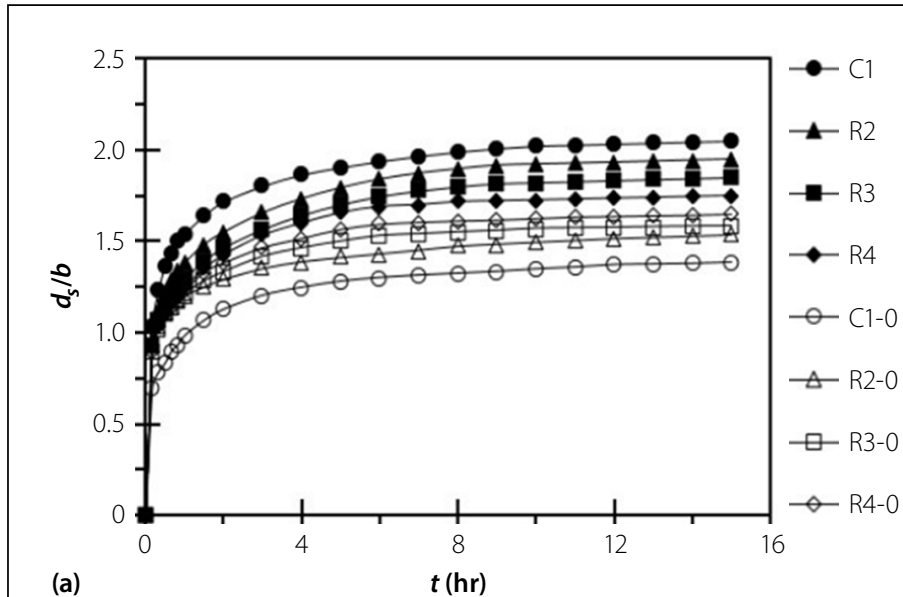

(a)

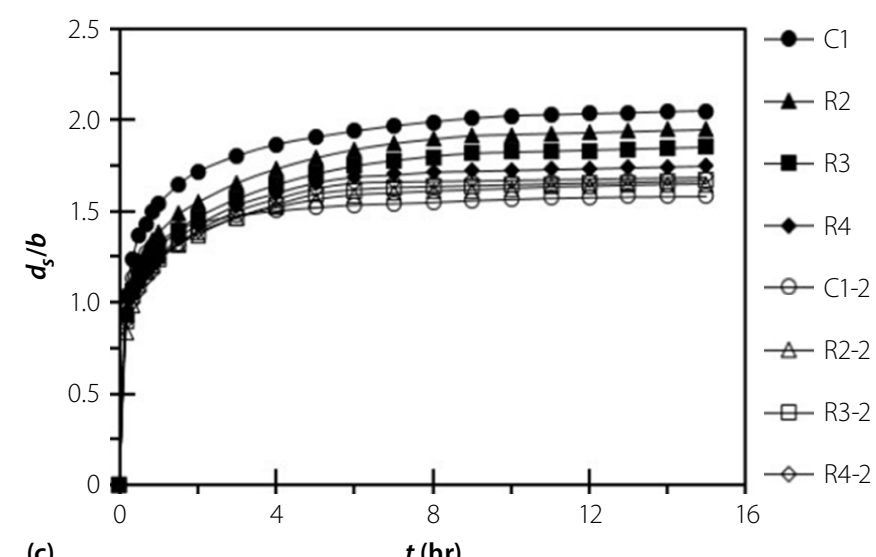

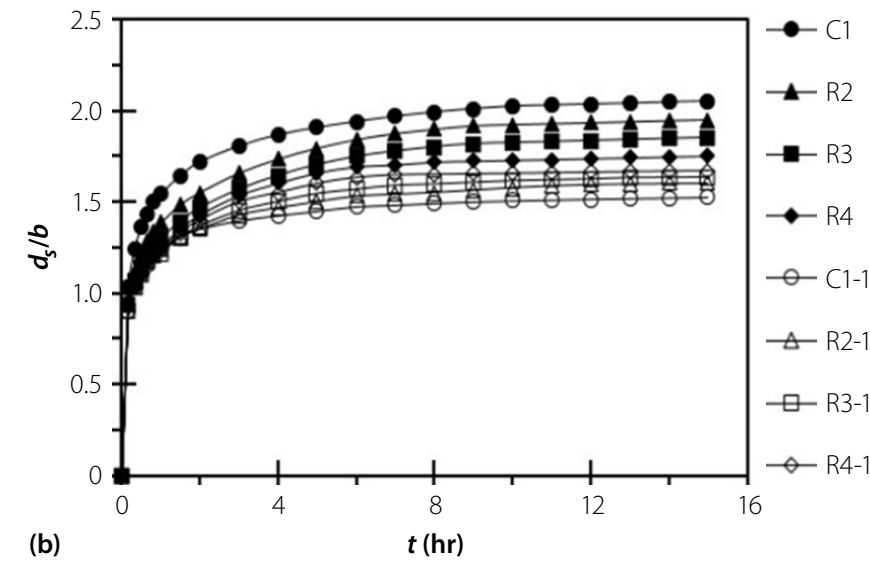

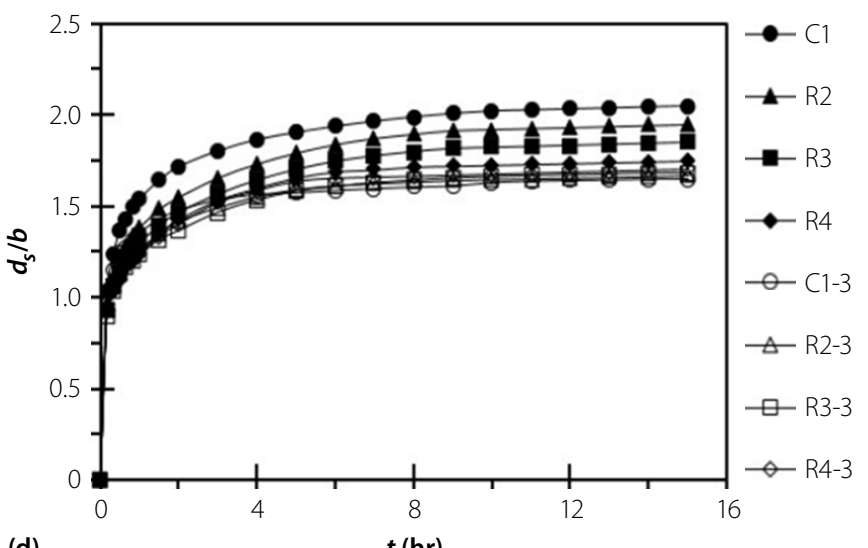

(d)

Figure 7 Temporal variations of the scour depth at piers with and without bed sill for different distances from the downstream side of the pier: (a) $D / b=0$, (b) $D / b=1$, (c) $D / b=2$ and (d) $D / b=3$ 

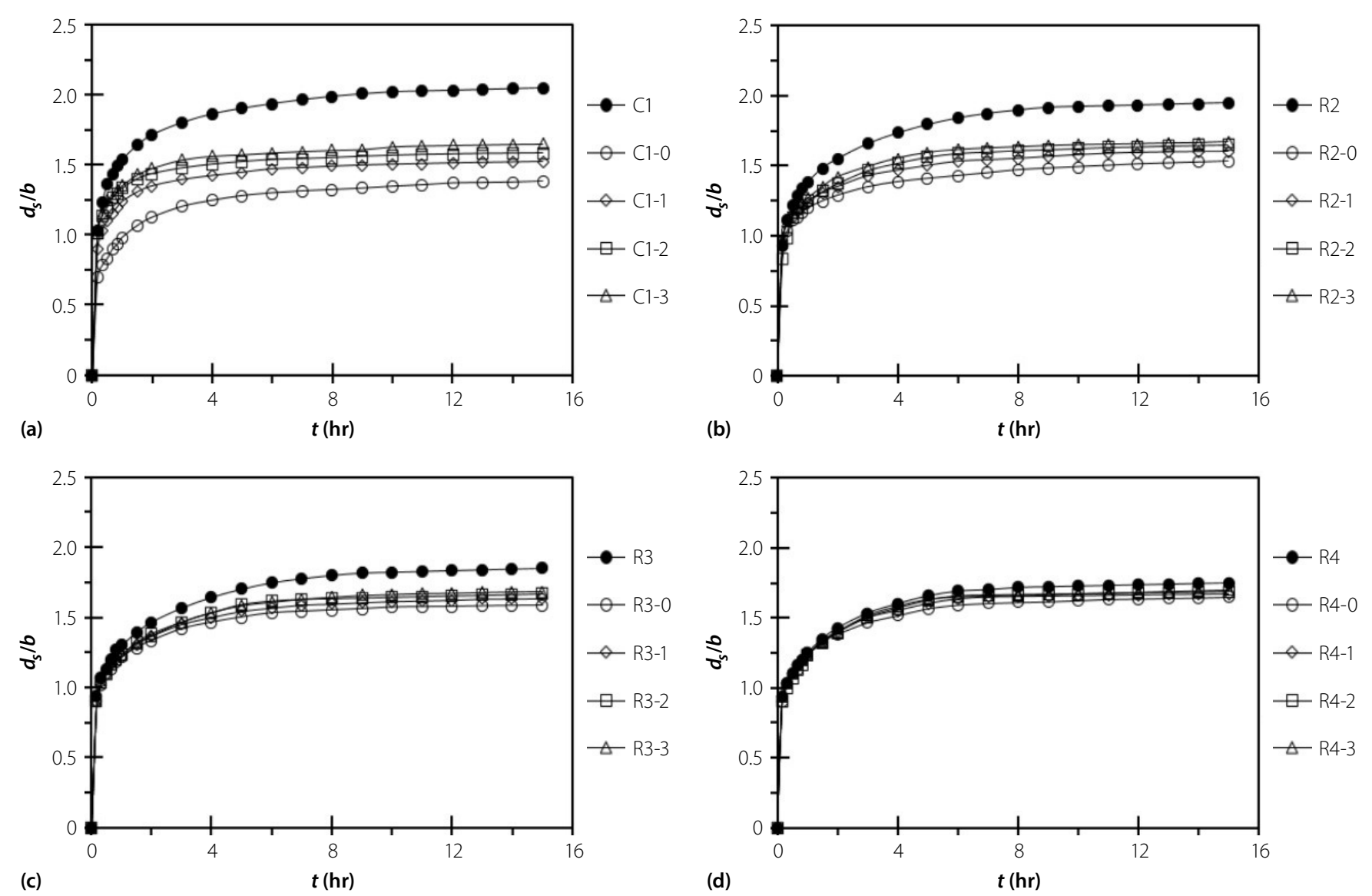

Figure 8 Temporal variations of the scour depth at the piers with and without bed sill for different length-to-width ratios: (a) $L / b=1,(b) L / b=2$, (c) $L / b=3$ and (d) $L / b=4$

piers with bed sill into the piers and those without bed sill are presented for different distances of the bed sill from the downstream side of the bridge pier in Figure 7. The percentage reduction of the local scour depth of the circular and round-nosed rectangular piers with bed sill into the piers and those without bed sill is also presented in Table 2. The results, as presented in Figure 7, showed that the scour depth variations were very high in the early phases of the experiments, but over time the intensity of these variations was diminished. The bed sill used in this study acted as a protective agent against local scour, influencing the horseshoe vortex and, particularly, the wake vortices. In addition, the results indicated that, by increasing the $L / b$ ratio at the piers with bed sill, the scour depth increased and bed sill performance was decreased. Therefore, it could be stated that the bed sill performance for the pier with $L / b=1$ outweighed that for the pier with $L / b=4$.

\section{The effect of increase $(D / b)$ \\ on the local scour depth}

Temporal variations of the scour depth based on the variations in the distance of the bed sill from the downstream side of the circular and round-nosed rectangular piers are presented for different length-towidth ratios, $L / b$, in Figure 8. In addition, according to Table 2, the bed sill performance in terms of reducing the local scour depth of the circular and round-nosed rectangular piers was calculated and presented. In all experiments, the scour depth was measured and shown at different time intervals. Sixteen tests were carried out to investigate the bed sill performance at the piers with ratios $(L / b) 1,2,3$ and 4; the details of each experiment are presented in Table 2. The results indicated that the bed sill, as a protective agent on the back of the pier, reduced the scour depth $\left(d_{s}\right)$ and its use led to a significant decrease in the local scour depth of the bridge piers, particularly for the circular pier. The results also revealed that, by distancing the bed sill from the back of the pier towards downstream, the bed sill had less effect on reducing the local scour depth. In addition, it could be seen that when increasing the $L / b$ ratio, the bed sill performance at different $D / b$ intervals was decreased - see Figures $8(\mathrm{a})$ and 8 (b). Therefore it could be expressed that the highest decrease in the local scour depth by the bed sill for the best combination $L / b=1, D / b=0$, and the lowest decrease in the local scour depth for the combination $L / b=4, D / b=3$ were observed, i.e. approximately $32.5 \%$ and $2.9 \%$, respectively (Table 2 ). Regardless of the increase of the $L / b$ ratio, at $L / b=4$ the use of the bed sill did not have much effect on reducing the scour depth and the temporal development of the local scour depth at the piers where the bed sill was almost equal to those without bed sill - see Figure 8(d).

\section{Performance of the bed sill in the circular pier}

Figure 9 indicates the performance of the bed sill at different distances downstream of the circular pier (C1-0, C1-1, C1-2 and C1-3 tests). For comparison, the results obtained by Grimaldi et al (2009a) are included. As shown in Figure 9, the smaller the distance between the bed sill and pier, the larger the effectiveness of the countermeasure. Grimaldi et al (2009a) also found that the bed sill effectiveness was increased as $D$ was decreased. The maximum efficiency was achieved when the bed sill was placed just adjacent to the downsream face of the 


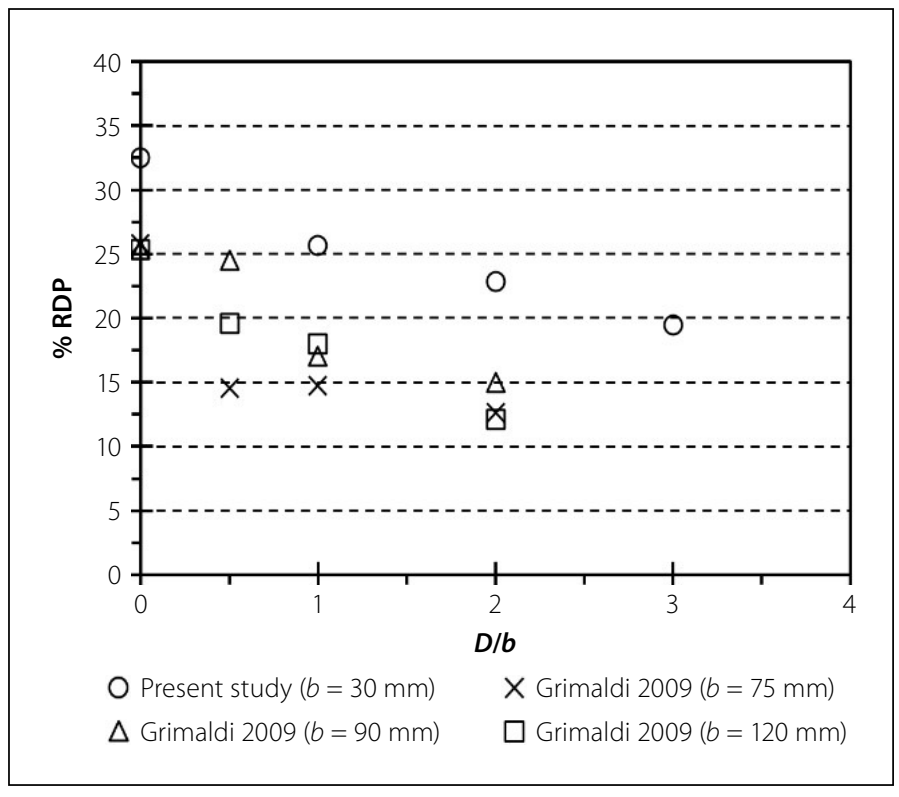

Figure 9 Performance of the bed sill at different distances downstream of the circular pier (C1-0, C1-1, C1-2 and C1-3 tests)

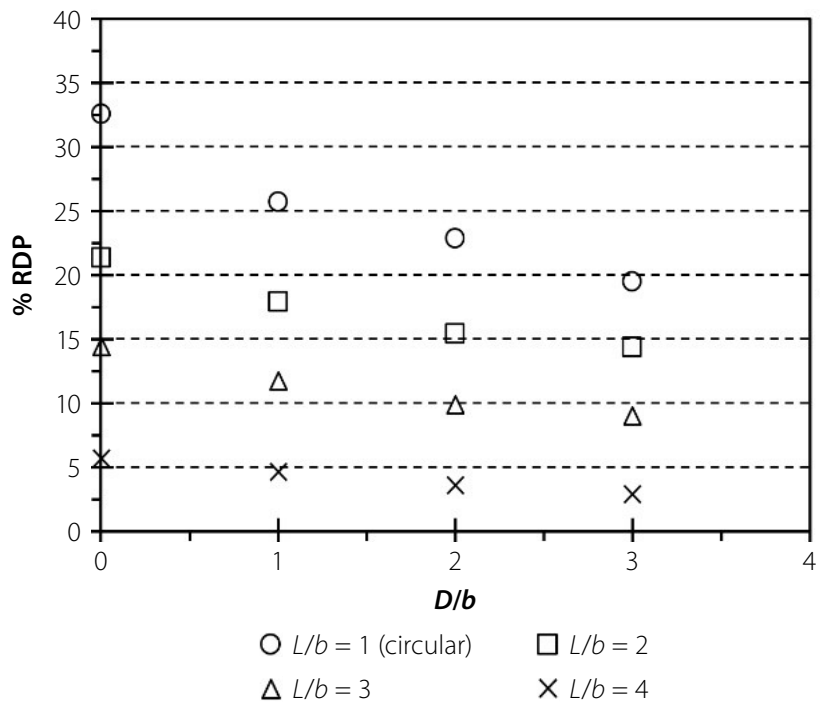

Figure 10 Effectiveness of the bed sill in reducing the local scour at the circular pier and the rectangular round-nosed ones circular pier, i.e. $D / b=0$ (32.5\%). The same results were obtained by Grimaldi et al (2009a) and Tafarojnoruz et al (2012a). When the bed sill is close to the pier, $D=0$, the bed sill entirely eliminates the wake vortex system from the scour volume around the pier and changes the flow field, as well as affects the horseshoe vortex; this results in the maximum performance of the bed sill in the reduction of local scouring at the pier nose. When $D$ is increased $(D>0)$, the bed sill seems to affect the horseshoe vortex, further disturbing the lower part of the wake vortex system, with a performance less than that for $D=0$. The difference of performance in the present study and that of Grimaldi et al (2009a) could be related to the duration of the experiments. The duration of tests in the present study was 15 hours, based on the Vittal et al (1994) equilibrium criteria, while it was 96 hours in the study performed by Grimaldi et al (2009a) according to equilibrium criteria proposed by Grimaldi (2005) .

\section{Performance of the bed sill in the round-nosed rectangular pier}

Figure 10 shows the effectiveness of the bed sill in reducing the local scour at the circular pier and rectangular round-nosed piers having different length-to-width ratios. For all piers, the bed sills were located at four different distances downstream of the pier. As can be clearly seen from Figure 10, for the round-nosed rectangular piers, similar to the circular pier, the maximum efficiency of the bed sill occurred when it was positioned downstream of the pier and attached to it, that was $D / b=0$; it was decreased with increasing its distance from the pier. Figure 10 clarifies that at a certain $D / b$, the efficiency of the bed sill in the round-nosed rectangular pier was significantly reduced, compared to the circular one. In round-nosed rectangular piers, for a certain $D / b$, the efficiency was decreased with increasing pier length.

\section{CONCLUSIONS}

The scour depth of the rectangular piers was lower than that of the circular ones at all phases of temporal development. Also, the scour depth decreased with an increasing length-to-width ratio. The efficiency decreased with an increasing length-towidth ratio of the piers. In round-nosed rectangular piers, similar to the circular piers, the maximum efficiency of the bed sill occurred when the bed sill was attached to the downstream end of the pier. The efficiency decreased with an increase in the bed sill distance from the downstream end of the pier. To conclude, although the use of bed sill is suitable for reducing the local scour in the circular piers, its effectiveness at round-nosed rectangular piers is significantly reduced when the length-to-width ratio is greater than 2 . This means that when the bed sill is attached to the pier, the efficiency is decreased from $32.5 \%$ for the circular pier to $5.7 \%$ for the rectangular one with a length-to-width ratio of 4 . Therefore, the application of the bed sill cannot be recommended for reducing the local scouring in round-nosed rectangular piers when the length-to-width ratio is greater than 2 .

\section{REFERENCES}

Barkdoll, B B, Melville, B W \& Chiew, Y M 2000. Time scale for local scour at bridge piers. Journal of Hydraulic Engineering, 126(10): 793-795.

Breusers, H N C \& Raudkivi, A J 1991. Scouring: Hydraulic Structures Design Manual No. 2. Rotterdam: Taylor and Francis.

Breusers, H N C, Nicollet, G \& Shen, H W 1977. Local scour around cylindrical piers. Journal of Hydraulic Research, 15(3): 211-252.

Cardoso, A H \& Bettess, R 1999. Effects of time and channel geometry on scour at bridge abutments. Journal of Hydraulic Engineering, 125(4): 388-399.

Chiew, Y M \& Lim, S 2003. Protection of bridge piers using a sacrificial sill. Proceedings of the Institution of Civil Engineers - Water and Maritime Engineering, 156(1): 53-62.

Chiew, Y M 1984. Local scour at bridge piers. PhD thesis. Auckland, New Zealand: University of Auckland.

Chiew, Y M 2004. Local scour and riprap stability at bridge piers in a degrading channel. Journal of Hydraulic Engineering, 130(3): 218-226.

Dey, S \& Barbhuiya, A K 2004. Clear-water scour at abutments in thinly armored beds. Journal of Hydraulic Engineering, 130(7): 622-634. Ettema, R 1980. Scour at bridge piers. PhD thesis. Auckland, New Zealand: University of Auckland. Franzetti, S, Malavasi, S \& Piccinin, C 1994. Sull' erosionealla base delle pile di ponte in acquechiare. Proceedings, XXIV Convegno di Idraulica e Costruzioni Idrauliche [35th Conference on Hydraulics and Hydraulic Constructions] 16-18 September 1994, Turin, Italy, pp 1-13.

Garde, R J 1970. Initiation of motion on a hydrodynamically rough surface-critical velocity approach. Water and Energy International, 27(3): 271-282. 
Gaudio, R \& Marion, A 2003. Time evolution of scouring downstream of bed sills. Journal of Hydraulic Research, 41(3): 271-284.

Gaudio, R, Marion, A \& Bovolin, V 2000. Morphological effects of bed sills in degrading rivers. Journal of Hydraulic Research, 38(2): 89-96.

Gaudio, R, Tafarojnoruz, A \& Calomino, F 2012. Combined flow-altering countermeasures against bridge pier scour. Journal of Hydraulic Research, 50(1): 35-43

Ghorbani, B \& Kells, J A 2008. Effect of submerged vanes on the scour occurring at a cylindrical pier. Journal of Hydraulic Research, 46(5): 610-619.

Goncharov, V N 1964. Dynamics of Channel Flow. Jerusalem: Israel Program for Scientific Translations.

Grimaldi, C 2005. Non-conventional countermeasures against local scouring at bridge piers. $\mathrm{PhD}$ dissertation. Arcavacata, Italy: University of Calabria.

Grimaldi, C, Gaudio, R, Calomino, F \& Cardoso, A H 2009a. Control of scour at bridge piers by a downstream bed sill. Journal of Hydraulic Engineering, 135(1): 13-21.

Grimaldi, C, Gaudio, R, Calomino, F \& Cardoso, A H 2009b. Countermeasures against local scouring at bridge piers: Slot and combined system of slot and bed sill. Journal of Hydraulic Engineering, 135(5): 425-431.

Guo, J 2014. Semi-analytical model for temporal clear water scour at prototype piers. Journal of Hydraulic Research, 52(3): 366-374.

Hager, W H \& Oliveto, G 2002. Shields' entrainment criterion in bridge hydraulics. Journal of Hydraulic Engineering, 128(5): 538-542.
Kramer, H 1935. Sand mixtures and sand movement in fluvial model. Transactions of the American Society of Civil Engineers, 100(1): 798-838.

Kumar, V, Raju, K G R \& Vittal, N 1999. Reduction of local scour around bridge piers using slots and collars. Journal of Hydraulic Engineering, 125(12): 1302-1305.

Lagasse, P F \& Richardson, E V 2001. ASCE compendium of stream stability and bridge scour papers. Journal of Hydraulic Engineering, 127(7): 531-533.

Lagasse, P F, Clopper, P E, Pagán-Ortiz, J E, Zevenbergen, L W, Arneson, L A, Schall, J D \& Girard, L G 2009. Bridge scour and stream instability countermeasures: experience, selection, and design guidance. Vol 1. Report No. FHWA-NHI-09-111. Washington, DC: National Highway Institute (US).

Laursen, E M \& Toch, A 1956. Scour around bridge piers and abutments. Vol 4. Ames, IA: Iowa Highway Research Board.

Laursen, E M 1963. An analysis of relief bridge scour. Journal of the Hydraulics Division, 89(3): 93-118.

Lefter, J 1993. Instrumentation for measuring scour at bridge piers and abutments. NCHRP Research Results Digest, Issue No. 189.

Lee, S O \& Strum, T W 2009. Effect of sediment size scaling on physical modelling of bridge pier scour. Journal of Hydraulic Engineering, 135(10): 793-802.

Lenzi, M A, Marion, A \& Comiti, F 2003. Interference processes on scouring at bed sills. Earth Surface Processes and Landforms: The Journal of the British Geomorphological Research Group, 28(1): 99-110.

Martin-Vide, J P \& Andreatta, A 2009. Channel degradation and slope adjustment in steep streams controlled through bed sills. Earth Surface Processes and Landforms, 34(1): 38-47.
Melville, B W \& Chiew, Y M 1999. Time scale for local scour at bridge piers. Journal of Hydraulic Engineering, 125(1): 59-65.

Melville, B W \& Coleman, S E 2000. Bridge Scour. Littleton, CO: Water Resources Publications.

Melville, B W \& Sutherland, A J 1988. Design method for local scour at bridge piers. Journal of Hydraulic Engineering, 114(10): 1210-1226.

Neill, C R 1967. Mean-velocity criterion for scour of coarse uniform bed-material. Proceedings, 12th Congress of the International Association for Hydraulic Research, 11-14 September 1967, Fort Collins, CO, pp 46-54.

Pagliara, S, Carnacina, I \& Cigni, F 2010. Sills and gabions as countermeasures at bridge pier in presence of debris accumulations. Journal of Hydraulic Research, 48(6): 764-774.

Razi, S, Salmasi, F, Dalir, A H \& Farsadizaeh, D 2011. Application of bed sill to control scouring around cylindrical bridge piers. Journal of Civil Engineering and Urbanism, 2: 115-121.

Tafarojnoruz, A, Gaudio, R \& Calomino, F 2012a. Evaluation of flow-altering countermeasures against bridge pier scour. Journal of Hydraulic Engineering, 138(3): 297-305.

Tafarojnoruz, A, Gaudio, R \& Calomino, F 2012b. Bridge pier scour mitigation under steady and unsteady flow conditions. Acta Geophysica, 60(4): 1076-1097.

Tregnaghi, M, Marion, A \& Gaudio, R 2007. Affinity and similarity of local scour holes at bed sills. Water Resources Research, 43(11): 1-11.

Vittal, N, Kothyari, U C \& Haghighat, M 1994. Clearwater scour around bridge pier group. Journal of Hydraulic Engineering, 120(11): 1309-1318. 